\title{
Influence of Free-Stall Base on Tarsal Joint Lesions and Hygiene in Dairy Cows
}

\author{
W. K. Fulwider, ${ }^{\star 1}$ T. Grandin, ${ }^{*}$ D. J. Garrick, ${ }^{*}$ T. E. Engle, ${ }^{\star}$ W. D. Lamm, ${ }^{\star}$ N. L. Dalsted, $†$ and B. E. Rollin ${ }^{\star} \ddagger \S$ \\ *Department of Animal Sciences, \\ †Department of Agricultural and Resource Economics, \\ $\ddagger$ Department of Philosophy, and \\ $\S$ Department of Biomedical Sciences, Colorado State University, Fort Collins 80523
}

\begin{abstract}
The objective was to quantify the incidence of tarsal lesions and level of hygiene by stall bed type. Cows were scored on 100 dairies from Wisconsin, Minnesota, Indiana, Iowa, and New York in the fall and winter. Thirty-eight dairies used rubber-filled mattresses (RFM), 27 had sand beds, 29 had waterbeds, and 6 used compost packs $(\mathrm{CPk})$. Stocking density, stall dimensions, bedding amount, bedding frequency, and type of bedding were recorded. One pen of early-lactation multiparous cows on each dairy was scored based on injury of the tarsal joints at the lateral and medial surfaces and tuber calcis at the dorsal, lateral, and medial surfaces. A tarsal score of 1 represented hair loss, 2 was moderate, and 3 indicated severe swelling. Differences between bed types in the percentages of cows with lesions were tested with one-way ANOVA by lesion severity and incidence, with farm as the experimental unit. Cows on sand beds or waterbeds had fewer lesion scores of 1,2 , and 3 than those on RFM. The percentages of score 1 were $54.6 \pm 4.4(\mathrm{RFM}), 22.5 \pm$ 4.7 (sand), and $29.8 \pm 4.3$ (waterbed), whereas the percentages of score 2 were $14.0 \pm 1.4,2.3 \pm 1.5$, and 5.0 \pm 1.4 , and of score 3 were $3.0 \pm 0.4,0.2 \pm 0.4$, and 0.4 \pm 0.4 . Cows on $\mathrm{CPk}$ had no lesions. Hygiene scores ranged from 1 to 5 , with 1 being clean and 5 soiled. The percentages of hygiene score 1 were 0 (compost), 0.4 (RFM), 0.4 (sand), and 0.4 (waterbeds); those with score 2 were $79.0,84.0 \pm 0.01,73.2 \pm 0.01$, and $80.4 \pm 0.01$; with score 3 were $20.3,15.2 \pm 0.01,23.8 \pm 0.01$, and $18.6 \pm 0.01$; with score 4 were $0.8,0.005 \pm 0.001,0.006$ \pm 0.001 , and $0.025 \pm 0.003$; and with score 5 was 0 for all bed types. Cows on RFM and waterbeds had improved hygiene compared with cows on sand beds. There was no difference in somatic cell count (SCC) by bed type. The percentage of cows in fourth lactation or
\end{abstract}

Received November 28, 2006.

Accepted March 5, 2007.

${ }^{1}$ Corresponding author: Wendy.Fulwider@ColoState.edu greater on waterbeds $(19.8 \pm 1.8)$ was greater than those on RFM $(13.3 \pm 1.6)$ or on sand (13.5 \pm 1.8$)$. The percentage culled was lower for cows on waterbeds than on RFM $(22.8 \pm 1.5$ vs. $29.4 \pm 1.4)$. Score 3 tarsal lesions were correlated $(r=0.60)$ with SCC. The length of the sand bed was correlated with a greater percentage of mature cows. The SCC was correlated with the percentage of cows reported lame on the day of the visit $(r=$ $0.45)$ and with neck rail height $(\mathrm{r}=-0.26)$. On dairies with RFM, severe lesions $(r=0.60)$, death losses $(r=$ 0.52 ), and percentage of the herd reported lame on the day of the visit $(\mathrm{r}=0.52)$ were all correlated with the SCC. Dairies with higher percentages of lesions had higher SCC, death losses, lameness, and culling rates. Adding bedding several times per week may reduce the incidence of lesions.

Key words: dairy cow, hygiene, lesion, stall bed

\section{INTRODUCTION}

Plumb (1893) demonstrated the economic and welfare advantages from housing dairy cows during the cold winter months rather than leaving them outside. The design and dimension of stalls affect their use by cows (Tucker et al., 2004). Cows should be able to perform the natural movements associated with getting up and lying down without injury; cows provided with a softer bed are known to stand up and lie down twice as often as cows on concrete (Haley et al., 2001). Cows should be provided comfortable, well-maintained beds (Tucker et al., 2006) and enough beds so they do not have to wait to lie down (Wierenga, 1990). The cushioning ability of stall beds is an important feature in stall design (Manninen et al., 2002; Fulwider and Palmer, 2004b).

Severe leg injuries may result in pain and suffering (Wechsler et al., 2000). Sogstad et al. (2006) reported that more clinical mastitis and teat injuries were associated with cows exhibiting tarsal wounds and swellings. According to Haley et al. (1999), mattresses were responsible for fewer leg injuries than concrete stalls. 
Fewer leg injuries were reported for cows maintained on deep-bedded stalls vs. rubber-filled mattresses (RFM; Weary and Taszkun, 2000). Wechsler et al. (2000) noted that cows bedded with straw had fewer scabs, wounds, and hairless tarsal joints than those in free stalls with soft lying mats. Tucker et al. (2003) noted that lying surface affected udder health, and although the relationship between organic bedding and mastitis is well known, the costs associated with maintaining deep-bed systems resulted in increased RFM use. Cow preferences for softer lying surfaces corresponded with reduced incidence and severity of leg injuries in dairy cows (Tucker et al., 2003). Westerath et al. (2006) found that tarsal joint lesion scores in finishing bulls increased steadily over time depending on whether they were kept on slatted concrete, slatted concrete with rubber, or free stalls with a foamed ethylene vinyl acetate mat, a rubber mat, or an RFM. Sand stalls were protective with regard to tarsal joint lesions, whereas RFM provided no advantage when compared with concrete stalls (Vokey et al., 2001). Sand is considered by many as the ideal stall surface for injury reduction, although stall maintenance is an issue.

Bewley et al. (2001) reported that Wisconsin dairy producers felt sand provided some cow comfort advantages, but indicated higher satisfaction with bedding costs and manure handling in mattress-based systems. They found no difference in rolling herd average (RHA) milk production or SCS among herds with these bed types. Cow preference tests (Wagner-Storch et al., 2003; Fulwider and Palmer, 2004a) showed that waterbeds were low to intermediate in preference, because cows require time to adjust to the wobbly nature of this bed type.

Sand and RFM are among the most commonly used stall bases in the Midwest. Producers have strong opinions regarding these base types. Waterbeds have been the focus of few research projects, are relatively new, and are gaining in popularity because of the purported minimal bedding needs, low incidence of tarsal joint abrasion, and greater useful life as compared with other mattress types. Because of the novelty of compost pack (CPk) barns, 6 dairies using CPk were included in this study. The purpose of this study was to compare RFM, sand, and waterbed lying area surfaces for dairy cows with respect to tarsal joint lesions, hygiene, and SCC based on field data collected on many dairies.

\section{MATERIALS AND METHODS}

A total of 113 dairies in 5 states (Wisconsin, Minnesota, New York, Iowa, Indiana), with 90,162 cows, were visited during a 4-mo period beginning October 14, 2005. Because of a mixture of bed types within a pen, or ineligible bedding (foam mattress or rubber mat) or bedding types (recycled manure solids), only 94 dairies were included in the free-stall hygiene analysis. Cows were maintained on one base type for a minimum of 1 yr to be eligible for the tarsal joint and tuber calcis study, which limited data to 85 free-stall dairies. The free-stall dairy farm units ranged from 80 to 4,286 cows, with a mean of 803 cows. An attempt was made to visit equal numbers of dairies of each bed type in each state. Compost pack dairies were smaller in size, ranging from 66 to 195 cows, with a mean of 99 cows.

The North American manufacturer of cow waterbeds, Advanced Comfort Technology, Inc. (Reedsburg, WI), provided a list of dairies using waterbeds (55) plus neighboring dairies with sand (16), or RFM (26) for the selected states. Initial contact with producers was made and an appointment was requested within the week. Fifty-three additional dairies were included, for a total of 113 dairies, as a result of stopping at a dairy or by requesting names of local producers who might be willing to participate at the local veterinary office, feed mill, university extension office, equipment dealer, or participating producers.

Ninety-four dairies were included in the hygiene analysis (Table 1) because the bed or bedding type of the remaining dairies did not fit the study traits. Only 85 dairies had cows on a given bed type long enough to be included in the tarsal joint and tuber calcis analysis (Table 1). Production information, stocking density, stall dimensions, bedding amount, bedding frequency and type, and number of cows in fourth lactation or greater were recorded. All sand-stall dairies included in the analysis had a concrete manure curb at the rear of the stall. The bedding materials most commonly used by waterbed and RFM dairies included sawdust, rice hulls, chopped straw, or lime. Five free-stall dairies reused (recycled) sand, whereas all others bedded with new sand. None of the dairies included in the analysis used recycled manure or digester solids as bedding materials. Six CPk dairies in Minnesota were included as supplemental information, because $\mathrm{CPk}$ are a relatively new innovation and may be of interest to producers for cows with special needs.

One pen of cows that contained the highest numbers of early-lactation multiparous cows was individually scored in the parlor on each dairy at milking time. All scores were assigned by one individual. If the dairy had more than one pen of cows that fit the above criteria, the pen with the oldest cows was measured.

\section{Leg Lesion Measurements}

Five areas on both rear legs were scored for skin lesions. These were lateral and medial surfaces of the 
Table 1. Farms visited and cows recorded for tarsal joint lesions ${ }^{1}$ and hygiene by free-stall bed type included in the analysis

\begin{tabular}{lcccc}
\hline Stall bed type & $\begin{array}{c}\text { Tarsal-scored } \\
\text { farms }\end{array}$ & $\begin{array}{c}\text { Tarsal-scored } \\
\text { cows }\end{array}$ & $\begin{array}{c}\text { Hygiene-scored } \\
\text { farms }\end{array}$ & $\begin{array}{c}\text { Hygiene-scored } \\
\text { cows }\end{array}$ \\
\hline Compost $^{2}$ & 6 & 399 & 6 & 399 \\
Rubber-filled mattress & 31 & 3,615 & 38 & 4,131 \\
Sand & 26 & 3,651 & 27 & 3,855 \\
Waterbed & 28 & 2,561 & 29 & 2,725 \\
Total & 91 & 10,226 & 100 & 11,110 \\
\hline
\end{tabular}

${ }^{1}$ Fewer farms were included in the tarsal study because cows were required to be on the specified bed type for a minimum of $1 \mathrm{yr}$.

${ }^{2}$ Compost pack included as supplemental information.

tarsal joint and the lateral, medial, and dorsal surfaces of the tuber calcis. This was similar to the 2-point scoring system used by Weary and Taszkun (2000), but extended to a 4-point scale. The following scores were assigned: 0 (no hair loss or swelling), 1 (hair loss, no swelling), 2 (swelling), or 3 (severe swelling). Hair loss patches (score 1) were $1.8 \mathrm{~cm}$ in diameter or larger. Score 2 swellings were smaller than $7.4 \mathrm{~cm}$ in diameter and may or may not have had a dry scab, but had no bleeding or drainage. Swellings larger than $7.4 \mathrm{~cm}$ in diameter were assigned score 3 and may have been purulent, extensive, or bleeding. If a cow suffered hair loss or swelling, both legs were generally affected. If a cow suffered a number of lesions on both legs, this was noted, but only the most severe lesion per location was used in the analysis. Whenever knees could be scored without interrupting cow flow in the parlor, scores of $0,1,2$, or 3 were assigned using the same scoring system. All injuries observed were noted.

\section{Cow Hygiene Measurements}

Hygiene scores were assigned to every cow in the selected pen. Each cow was assigned a score, with 1 being clean and 5 being soiled. The hygiene score card used by Reneau et al. (2005) was used as a guide. A hygiene score of 1 was assigned to cows with no visible manure stains or dried manure. A score of 2 was given to cows with manure stains but no visible dried manure on the legs or udder. Cows with dried or wet manure on the legs or udder received a score of 3 . Heavily soiled cows were assigned a score of 4 , whereas a score of 5 was reserved for cows that had both manure stains and dried manure on the legs, udder, and ventral abdomen (i.e., alley-layers).

\section{Production Information}

Rolling herd averages for milk, fat, protein, SCC, cow age, number of mature cows defined as fourth lactation or greater, culling rate, and annual death rate were provided from herd records. Data were collected regarding the frequency of cleaning the barn and stall bedding, the bedding type, and the number of cows lame on the day of the visit.

\section{Statistical Analysis}

Lesion scores were analyzed as the percentage of cows per farm with lesions and by the percentage of cows with a specific lesion location. Differences in tarsal joint and tuber calcis lesions, lesion severity, hygiene percentages, and hygiene level between bed types were analyzed with a completely randomized one-way ANOVA with farm as the experimental unit (SAS 9.1, 2002-2003, SAS Institute, Inc., Cary, NC). Pairwise comparisons were compiled using $t$-tests when there were significant differences between bed types. Fisher's protected least significant difference test ( $t$-test) was performed to control the error rate for pairwise comparisons; that is, pairwise comparisons were done only if the ANOVA $F$-test was significant. Pearson correlations were used for comparing lesion scores, hygiene scores, and production measures.

\section{RESULTS AND DISCUSSION}

\section{Tarsal Lesions}

Cows on RFM dairies had more score $1(P \leq 0.0001)$, $2(P<0.0001)$, and $3(P<0.0001)$ lesions than cows on sand or waterbeds (Table 2). Cows on CPk exhibited no lesions of any kind, with the exception of a few cows on one dairy that were recently purchased from a freestall facility. There was no difference between cows on sand or waterbeds with regard to lesion score, although there was a difference in lesion location. When broken down by lesion location, cows on RFM had more lateral tarsal joint lesions $(P<0.01)$ than those on sand, and had more $(P<0.03)$ than cows on waterbeds (Table 3 ). There was no difference between the 3 bed types regarding medial surface tarsal joint lesions. The only comparison that resulted in a difference for lesions on 
Table 2. Influence of free-stall bed type on the percentage of cows with various lesion scores

\begin{tabular}{lrrrr}
\hline & \multicolumn{4}{c}{ Lesion score $^{1}$} \\
\cline { 2 - 5 } Stall bed type & \multicolumn{1}{c}{0} & 1 (SEM) & 2 (SEM) & 3 (SEM) \\
\hline Compost $^{2}$ & 100.0 & 0.0 & 0.0 & 0.0 \\
Rubber-filled mattress & 28.4 & $54.6^{\mathrm{a}, \mathrm{x}}(4.4)$ & $14.0^{\mathrm{a}}(1.4)$ & $3.0^{\mathrm{a}}(0.4)$ \\
Sand & 75.0 & $22.5^{\mathrm{b}}(4.7)$ & $2.3^{\mathrm{b}}(1.5)$ & $0.2^{\mathrm{b}}(0.4)$ \\
Waterbed & 64.8 & $29.8^{\mathrm{y}}(4.3)$ & $5.0^{\mathrm{b}}(1.4)$ & $0.4^{\mathrm{b}}(0.4)$ \\
\hline
\end{tabular}

${ }^{\mathrm{a}, \mathrm{b}}$ Percentages within columns with different superscripts are different $(P<0.0001)$.

${ }^{\mathrm{x}, \mathrm{y}}$ Percentages within columns with different superscripts are different $(P=0.0001)$.

${ }^{1}$ Lesion score 0 was no hair loss or swelling. Lesion score 1 represented hair loss on the tarsal joint or tuber calcis, $1.8 \mathrm{~cm}$ in diameter or larger and no swelling. Lesion score 2 was swelling no larger than 7.4 $\mathrm{cm}$ in diameter with no bleeding or drainage. Lesion score 3 was swellings larger than $7.4 \mathrm{~cm}$ in diameter and may have been bleeding or purulent.

${ }^{2}$ Compost pack included as supplemental information, not analyzed.

the lateral tuber calcis was between cows on sand or waterbeds $(P=0.03)$, with cows on sand having fewer. Only $1 \%$ of affected cows on sand or waterbeds suffered lesions that involved swelling, whereas $2 \%$ of cows on RFM had swelling at the lateral tuber calcis location. A greater percentage of cows on sand had dorsal lesions $(P<0.0001)$ compared with cows on RFM or waterbeds, likely because of abrasion with the concrete curb in deep-bed stalls.

Pearson correlations with 85 farms (RFM, sand, and waterbeds) indicated a negative correlation between frequencies of lesion score 2 and stall length $(\mathrm{r}=-0.23$, $P=0.05)$. The present study is in agreement with Weary and Taszkun (2000), with lesions being the most prevalent on cows with RFM beds. The lateral tarsal joint and lateral tuber calcis were the most affected locations on cows with RFM beds in both studies, although those authors reported a higher percentage of cows affected (91\%). Their study included 6 RFM dairies in the Pacific Northwest, and the use of different or more abrasive bedding materials may have been a factor. Cows on sand beds were similarly affected (24\%) in their study, with the dorsal tuber calcis being the most often injured location, perhaps as a result of contact with the concrete curb when sand becomes low. These injuries may be prevented by bedding more frequently, which could be advantageous in controlling Streptococcus spp., as suggested by Kristula et al. (2005), who further noted that sand stalls are generally filled only once weekly. Low percentages of cows suffered lesions at the medial surface of the tarsal joint (3.0, 4.8, and 2.7) on RFM, sand, or waterbeds, respectively. Cows with lesions at the medial tuber calcis were more common $(13.4,20.0$, and $17.5 \%$ ) on RFM, sand, or waterbeds, respectively. Sandbedded cows had the highest proportion (20\%) of medial tuber calcis lesions (Table 3), which differs from the report of Weary and Taszkun (2000). This may be the result of short sand lying areas, stalls not maintained as full, and subsequent abrasion on the concrete curb.

\section{Knee Lesions}

Hairless knees were frequently observed (28 to $61 \%$ of cows on 7 dairies) on dairies when cows were bedded with coarse or recycled sand containing larger particles. Knees were swollen on 7 to $11 \%$ of cows on 3 dairies that used coarse sand. When dairies using sand and recycled sand were compared for average knee scores, dairies using recycled sand had more $(P=0.04)$ cows with hairless knees than those using new sand. Fifty

Table 3. Influence of free-stall bed type on percentage of affected cows and lesion location

\begin{tabular}{lcclcccc}
\hline & \multicolumn{2}{c}{ Tarsal joint } & & \multicolumn{3}{c}{ Tuber calcis } \\
\cline { 2 - 3 } \cline { 7 - 8 } Stall bed type & Lateral (SEM) & Medial (SEM) & & Lateral (SEM) & Dorsal & Medial (SEM) \\
\hline Compost $^{1}$ & 0.0 & 0.0 & & 0.0 & 0.0 & 0.0 \\
Rubber-filled mattress & $81.9^{\mathrm{a}, \mathrm{r}}(0.3)$ & $3.0(0.5)$ & & $49.7(0.2)$ & $2.7^{\mathrm{y}}$ & $13.4(0.3)$ \\
Sand & $17.8^{\mathrm{s}}(0.3)$ & $4.8(0.5)$ & & $29.2^{\mathrm{b}}(0.3)$ & $29.4^{\mathrm{x}}$ & $20.0(0.3)$ \\
Waterbed & $40.9^{\mathrm{b}}$ & 2.7 & & $67.4^{\mathrm{a}}$ & $1.9^{\mathrm{y}}$ & 17.5 \\
\hline
\end{tabular}

${ }^{a, b}$ Percentage within columns with different superscripts are different $(P=0.03)$.

${ }^{\mathrm{r}, \mathrm{s}}$ Percentage within columns with different superscripts are different $(P=0.01)$.

x,y Percentage within columns with different superscripts are different $(P<0.0001)$.

${ }^{1}$ Compost pack included as supplemental information. 
Table 4. Influence of stall bed type on percentage of cows and hygiene score

\begin{tabular}{lllll}
\hline & \multicolumn{4}{c}{ Hygiene score $^{1}$} \\
\cline { 2 - 5 } Stall bed type & 1 (SEM) & $2($ SEM) & $3($ SEM) & 4 (SEM) \\
\hline Compost $^{2}$ & 0.0 & 79.0 & 20.3 & 0.8 \\
Rubber-filled mattress & $0.4(0.00)$ & $84.0^{\mathrm{a}}(0.01)$ & $15.2^{\mathrm{b}}(0.01)$ & $0.4^{\mathrm{b}}(0.00)$ \\
Sand & $0.4(0.00)$ & $73.2^{\mathrm{b}}(0.01)$ & $23.8^{\mathrm{a}}(0.01)$ & $2.5^{\mathrm{a}}(0.00)$ \\
Waterbed & $0.4(0.00)$ & $80.4^{\mathrm{a}}(0.01)$ & $18.6^{\mathrm{b}}(0.01)$ & $0.6^{\mathrm{b}}(0.00)$ \\
\hline
\end{tabular}

\footnotetext{
${ }^{\mathrm{a}, \mathrm{b}}$ Percentages within columns with different letters are different $(P<0.0001)$.

${ }^{1}$ Score 1 represents cows with no visible manure stains or dried manure attached to them. Score 2 was given to cows with manure stains, but no visible dried manure on the legs or udder. Score 3 reflected cows with dried or wet manure on the legs or udder. Score 4 was assigned to heavily soiled cows.

${ }^{2}$ Compost pack barns may be of interest to larger producers as special needs facilities. It is included here as supplemental information.
}

percent of dairies with cows on waterbeds had some cows with hairless knees, whereas the average percentage for all dairies using waterbeds was $0.05 \pm 0.02$. The dairy with the most affected cows (hair loss, $15 \%$; swelling, 13\%) was the only dairy with a $10.2 \times 10.2$ $\mathrm{cm}$ cast-iron brisket locator. Cows may have bumped their knees against the iron when rising. The next 2 most affected waterbed dairies had knee hair loss of 8 and $7 \%$ and swelling of 3 and 1\%, respectively.

\section{Cow Hygiene}

Cows maintained on mattresses or waterbeds had greater proportions of lower hygiene scores than cows on sand $(P<0.0001$; Table 4$)$. Hygiene scores for cows on $\mathrm{CPk}$ were most similar to those for cows on waterbeds. Very few cows were assigned scores of 1 or 5 , and the numbers were not different. Dairies with RFM or waterbeds bedded more frequently $(P=0.02)$, at 3.9 times weekly, compared with sand dairies, which bedded 1.9 times weekly (Table 5). Somatic cell counts by bed type were not different (Table 5). Barns with RFM were cleaned more frequently (3.4/d) than those with either sand $(2.5 / \mathrm{d}, P=0.05)$ or waterbeds $(2.4 / \mathrm{d}$, $P=0.04$ ).

Pearson correlations were obtained for farms using RFM, sand, and waterbeds combined. Somatic cell counts were correlated with score 3 lesions $(r=0.32$, $P=0.003)$, annual death rate $(\mathrm{r}=0.34, P=0.002)$, and percentage of cows reported lame on the day of the visit $(\mathrm{r}=0.45, P<0.0001)$. There was a significant correlation ( $\mathrm{r}=0.60, P=0.0006)$ for score 3 lesions and SCC for RFM. Somatic cell count had a correlation $(\mathrm{r}=-0.46$, $P=0.01$ ) with stall length for dairies using RFM. This trait was positive and not significant for sand and waterbed bases. Stall width was correlated with SCC ( $\mathrm{r}=$ $-0.50)$ for RFM $(P=0.005)$, whereas it was negative and not significant for sand and waterbed bases.

Death rate $(\mathrm{r}=0.52, P<0.004)$ and cows reported lame on the day of the visit $(\mathrm{r}=0.52, P=0.002)$ were related to SCC in RFM herds. The SCC relationship was true for all 3 base types: 29 RFM dairies $(r=0.52$, $P=0.002), 27$ sand dairies $(\mathrm{r}=0.45, P=0.02)$, and 29 waterbed dairies $(\mathrm{r}=0.39, P=0.04)$. The lame cow percentages were correlated $(\mathrm{r}=-0.22)$ with neck rail height $(P=0.05)$. When dairies were split by thirds for

Table 5. Associations of bed type with percentage of mature cows, SCC, percentage culled, and weekly winter bedding frequency

\begin{tabular}{lcccc}
\hline Stall bed type & $\begin{array}{c}\text { Mature cows } \\
\text { (SEM) }\end{array}$ & $\begin{array}{c}\text { SCC, } 1,000 \text { cells/mL } \\
\text { (SEM) }\end{array}$ & $\begin{array}{c}\text { Cull cows }{ }^{2} \\
\text { (SEM) }\end{array}$ & $\begin{array}{c}\text { Bedding frequency } \\
\text { (SEM) }\end{array}$ \\
\hline Compost $^{4}$ & 19.4 & 176.7 & 20.4 & 0.3 \\
Rubber-filled mattress & $13.3^{\mathrm{s}}(1.6)$ & $241.5(14.5)$ & $29.4^{\mathrm{x}}(1.4)$ & $3.9^{\mathrm{a}}(0.5)$ \\
Sand & $13.5^{\mathrm{b}}(1.8)$ & $235.2(16.1)$ & $25.6(1.5)$ & $1.9^{\mathrm{b}}(0.6)$ \\
Waterbed & $19.8^{\mathrm{a}, \mathrm{r}}(1.8)$ & $232.5(15.2)$ & $22.8^{\mathrm{y}}(1.5)$ & $3.9^{\mathrm{a}}(0.6)$ \\
\hline
\end{tabular}

${ }^{\mathrm{a}, \mathrm{b}}$ Percentages with different superscripts within column differ $(P=0.02)$.

${ }^{\mathrm{r}, \mathrm{s}}$ Percentages with different superscripts within column differ $(P=0.01)$.

${ }^{\mathrm{x}, \mathrm{y}}$ Percentages with different superscripts within column $\operatorname{differ}(P=0.001)$.

${ }^{1}$ Mature cows are defined as those in fourth lactation or greater.

${ }^{2}$ Percentage of cows culled annually.

${ }^{3}$ Bedding frequencies are on a per week basis for winter months.

${ }^{4}$ Compost pack is included here as supplemental information. 
the percentage of cows with score 2 and 3 lesions, the best and worst for SCC were RFM $\left(219.7 \pm 24.3 \times 10^{3}\right.$ / $\left.\mathrm{mL}, 242.7 \pm 25.4 \times 10^{3} / \mathrm{mL}\right)$, sand $\left(228.9 \pm 28.1 \times 10^{3} /\right.$ $\left.\mathrm{mL}, 201.7 \pm 28.1 \times 10^{3} / \mathrm{mL}\right)$. and waterbeds $(232.0 \pm$ $26.7 \times 10^{3} / \mathrm{mL}, 251.0 \pm 26.7 \times 10^{3} / \mathrm{mL}$ ).

Poor hygiene of the hind legs and udder was associated with increased SCS (Schreiner and Ruegg, 2003; Reneau et al., 2005). Veissier et al. (2004) reported a tendency for soiling to increase as the number of stall beds per cow decreased. The farm with the cleanest cows had the least mastitis (Ward et al., 2002). Our study found no difference in SCC by bed type. A possible explanation for the lack of difference between bed types for SCC is that none of the dairies used recycled manure or digested solids as bedding. The average SCC for each bed type (Table 5), including $\mathrm{CPk}$, was lower than the 2005 national average of 296,000 cells/mL (Miller and Norman, 2006).

\section{Best and Worst Practices}

Because dairies in this study participated voluntarily, there may have been a bias toward inclusion of well-managed dairies. Dairies with RFM, which had the fewest cows affected by lesions and the least severe lesions, bedded daily or every other day with 1 to 1.4 $\mathrm{kg}$ of straw or nonirritating kiln-dried shavings. The main difference between dairies with the least and most severely affected cows was in the frequency of adding bedding. The dairy using RFM with the lowest percentage of cows with lesions (12\% lesion score $1 ; 2 \%$ lesion score 2; $0 \%$ lesion score 3 ) bedded daily with sawdust. When the top and bottom third of dairies using RFM were sorted by the percentage of cows with combined score 2 and 3 lesions, differences were found for RHA $(7,530 \pm 698 \mathrm{~kg}$ vs. $10,206 \pm 698 \mathrm{~kg} ; P=0.005)$. There was no relationship between milk production and lesions on sand or waterbed dairies. The third of cows on dairies using sand with the lowest lesion percentages $(0.0 \pm 1.3) \mathrm{had}$ an average RHA of $8,818 \pm 772 \mathrm{~kg}$, and the third with the highest lesion percentages $(4.8 \pm 1.3)$ had an average RHA of $9,070 \pm 772 \mathrm{~kg}$. The difference in RHA between these 2 groups of dairies was $P=0.71$. The third of cows on dairies with waterbeds with the lowest lesion percentages averaged $0.7 \pm 1.2$, whereas the third with the highest lesion percentages was 9.3 \pm 1.2 . There was no difference in RHA $(8,063 \pm 735 \mathrm{~kg})$ between these dairies. The third of RFM dairies with the fewest score 2 and 3 lesions $(4.19 \pm 1.14)$ had an average RHA of 7,530 $\pm 698 \mathrm{~kg}$, whereas the third with the most lesions $(27.0 \pm 1.1)$ averaged $10,206 \pm 698 \mathrm{~kg}$ $(P=0.005)$, which was the highest production for any third regardless of bed type.
On dairies with RFM, SCC, death loss, and the number of cows reported lame on the day of the visit were all positively correlated with the percentage of lesions. A possible explanation for the positive correlation between milk production and lesions on dairies with RFM is that stalls on these dairies may have been too short or narrow for the cows. Narrow stalls were correlated with a lesion score of $3(\mathrm{r}=-0.52, P=0.01)$ on dairies with RFM. There was a correlation between SCC and stall width $(-0.50, P=0.005)$, and stall length $(-0.46$, $P=0.01$ ). Dairy producers on dairies with RFM whose priority is maximum production may have constructed stalls with less space for their cows.

Lateral tarsal joint hair losses on 5 dairies with recycled sand were 18, 19, 19, 39, and 59\%. The dairy using recycled sand on which 59\% hairless lateral tarsal joints were found had beds that consisted of 95\% recycled sand. Four percent of their cows had score 2 lesions and $0 \%$ had score 3 lesions. These cows were among the most likely candidates in the sand category to have swollen tarsal joints. Recycled sand contains more large particles than new sand (Kristula et al., 2005), and this may have been a contributing factor in the increased lesion rates. When dairies using a sand base were sorted into thirds by the percentages of cows with combined score 2 and 3 lesions, differences were found between the best and worst by lesion percentages for annual death rate $(7.3 \pm 1.1$ vs. $4.1 \pm 1.1 \% ; P=0.04)$ and the percentage reported lame on the day of the visit (3.2 \pm 0.7 vs. $1.1 \pm 0.7 \% ; P=0.05)$.

Only one-third of the dairies visited had sand management that kept hair loss below 10\% of cows and swelling below $2 \%$. A dairy with RFM had the most cows (11\%) afflicted with severe (score 3 ) lesions, whereas the most affected cows on dairies with sand or waterbeds was $2 \%$. The actual sand lying area for cows ranged in length from 140 to $239 \mathrm{~cm}$; the concrete curb holding sand ranged from 8 to $28 \mathrm{~cm}$; and the sand area plus curb ranged from 165 to $284 \mathrm{~cm}$. The most important factor in keeping cows comfortable and preventing injury in sand stalls may be keeping the stalls filled (Drissler et al., 2005). Sand stalls were filled anywhere from 0.3 to 7 times weekly. Some curbs were beveled, which may make stalls more comfortable when sand levels become low and make them easier to rake clean. Sand bedding of high quality may be superior in preventing lesions, but sand that is coarse or contains sharp stone or rocks may result in more cows with tarsal joint hair loss and swellings than their counterparts on well-managed dairies with RFM or waterbeds.

The primary difference between the best and worst waterbed dairies for tarsal joint lesions was the frequency of bedding to keep the surface dry and nonabrasive. The bedding frequency on the best waterbed dair- 
ies was twice daily to every other day and used 0.45 to $1.40 \mathrm{~kg} / \mathrm{stall}$ per day of straw, kiln-dried shavings, or lime in combination with chopped straw or shavings. Dairies with more lesion-affected cows generally bedded once or twice weekly. One dairy with waterbeds had lesion-free cows and filled the front of the stall with sawdust twice weekly, allowing the cows free access to pull it back.

\section{Base Type Details}

$\boldsymbol{R F M}$. Producers with RFM were making every effort to make cows comfortable. Dairies with RFM had the lowest stocking density (at 99\%), had the highest neck rails $(118.5 \pm 1.2 \mathrm{~cm})$, had the widest stalls $(117.8 \pm 0.8$ $\mathrm{cm}$ ), were the least satisfied with cow comfort, and had the highest culling rate.

Sand. There is much variation in sand within a given geographic area, and even more among different regions of the country. Finer-grained sand was less abrasive and resulted in fewer hairless knees and lesions of the tarsal joints and tuber calcis.

Sand-stall dairies had the highest stocking density (at 107\%) and the narrowest stalls $(115.8 \pm 0.9 \mathrm{~cm})$. Sand stalls also had the shortest lying area when the concrete curb was subtracted from the bed length.

Three sand dairies had herd averages in excess of $13,608 \mathrm{~kg}$, the average being $8,171.9 \pm 107.0 \mathrm{~kg}$. One of these had only 1 cow with a score 1 lesion; stalls were bedded with screened, fine-grained dry silica sand and had a $106 \%$ stocking density (cows per stall). The second dairy had only score 1 lesions. These cows were bedded with fine-grained sugar sand and stocked at $107 \%$. The third dairy used recycled sand and had many cows with lesions (some with swelling) and with hairless knees (some swollen). This dairy was stocked at $125 \%$ and was similar to average dairies with RFM for the percentage of cows with score 2 and 3 lesions, but two-thirds fewer cows had score 1 lesions. The actual sand length of the bed was $127 \mathrm{~cm}$.

Waterbeds. These dairies were stocked at $103 \%$ and had a lower culling rate (Table 5) than those using RFM. The stall dimensions on dairies with waterbeds were intermediate between those with RFM and sand. Dairies using waterbeds had more mature cows (fourth lactation or greater) than those with RFM or sand.

$\boldsymbol{C P} \boldsymbol{k}$. Cows on these dairies had more freedom and no injuries because there were no stalls to contend with and few injury-causing obstacles in the barns. There is a greater requirement for bedding and it must be cultivated twice daily for proper maintenance. Barns are cleaned out entirely once yearly and then deepbedded. Bedding is added every 2 to $4 \mathrm{wk}$ as need indicates by the cleanliness of the cows. If a bedding type other than sawdust is used, it must be carefully considered because not all types of bedding lend themselves to this management system. Many free-stall producers visited during the study expressed interest in this type of barn for cows with special needs.

\section{CONCLUSIONS}

Cows on RFM suffered more lesions and had more severe lesions than cows on sand or waterbeds. There was a difference by bed type in the location of lesions. Cows kept on RFM or waterbeds had better hygiene than their counterparts on sand, because sand-laden manure was more likely to cling to the legs. Bedding frequency was greater for dairies using RFM and waterbeds than those with sand. Culling rates were lower on dairies with waterbeds than those with RFM, and lower on dairies with waterbeds than those on sand, which may have resulted in there being more fourthlactation and greater cows residing on dairies with waterbeds. All 3 bedding types can be used successfully, but attention to detail (stocking density, stall length, stall width) and frequency of filling or addition of nonabrasive bedding materials is essential for low lesion counts and clean cows. Severe leg lesions were correlated with SCC. Dairies with higher percentages of lesions had higher SCC, death losses, lameness, and culling rates.

\section{ACKNOWLEDGMENTS}

The authors acknowledge the financial support of Grandin Livestock Handling Systems, Inc. (Fort Collins, CO) and Advanced Comfort Technology, Inc. (Reedsburg, WI).

\section{REFERENCES}

Bewley, J., R. W. Palmer, and D. B. Jackson-Smith. 2001. An overview of experiences of Wisconsin Dairy Farmers who modernized their operations. J. Dairy Sci. 84:717-729.

Drissler, M., M. Gaworski, C. B. Tucker, and D. M. Weary. 2005. Freestall maintenance: Effects on lying behavior of dairy cattle. J. Dairy Sci. 88:2381-2387.

Fulwider, W. K., and R. W. Palmer. 2004a. Stall usage differences of thirteen different free-stall base types. Prof. Anim. Sci. 20:470-482.

Fulwider, W. K., and R. W. Palmer. 2004b. Use of impact testing to predict softness, cow preference, and hardening over time of stall bases. J. Dairy Sci. 87:3080-3088.

Haley, D. B., A. M. de Passillé, and J. Rushen. 2001. Assessing cow comfort: Effects of two floor types and two tie stall designs on the behaviour of lactating dairy cows. Appl. Anim. Behav. Sci. 71:105-117.

Haley, D. B., J. Rushen, and A. M. de Passillé. 1999. Effects of softer flooring on behaviour, health and productivity of dairy cows in tie-stall housing. Page 127 in Proc. 33rd Int. Soc. Appl. Ethology. K. M. Bøe, M. Bakken, and B. O. Braastad, ed. Agricultural University of Norway, Lillehammer, Norway. 
Kristula, M. A., W. Rogers, J. S. Hogan, and M. Sabo. 2005. Comparison of bacteria populations in clean and recycled sand used for bedding in dairy facilities. J. Dairy Sci. 88:4317-4325.

Manninen, E., A. M. de Passille, J. Rushen, M. Norring, and H. Saloniemi. 2002. Preferences of dairy cows kept in unheated buildings for different kind of cubicle flooring. Appl. Anim. Behav. Sci. 75:281-292.

Miller, R. H., and H. D. Norman. 2006. Somatic cell counts of milk from 2005 Dairy Herd Improvement herds during 2006. Animal Improvement Programs Laboratory, ARS-USDA, Beltsville, MD. Online. Available: http://www.aipl.arsusda.gov/publish/dhi/ current/sccrpt.htm.

Plumb, C. S. 1893. Does it pay to shelter milk cows in winter? Bulletin 47. Purdue Univ. Agric. Exp. Station, West Lafayette, IN.

Reneau, J. K., A. J. Seykora, B. J. Heins, M. I. Endres, R. J. Farnsworth, and R. F. Bey. 2005. Association between hygiene scores and somatic cell scores in dairy cattle. J. Am. Vet. Med. Assoc. 227:1297-1301.

Schreiner, D. A., and P. L. Ruegg. 2003. Relationship between udder and leg hygiene scores and subclinical mastitis. J. Dairy Sci. $86: 3460-3465$.

Sogstad, Å. M., O. Østerås, and T. Fjeldaas. 2006. Bovine claw and limb disorders related to reproductive performance and production diseases. J. Dairy Sci. 89:2519-2528.

Tucker, C. B., D. M. Weary, and D. Fraser. 2003. Effects of three types of free-stall surfaces on preferences and stall usage by dairy cows. J. Dairy Sci. 86:521-529.

Tucker, C. B., D. M. Weary, and D. Fraser. 2004. Free-stall dimensions: Effects on preference and stall usage. J. Dairy Sci. $87: 1208-1216$.
Tucker, C. B., G. Zdanowicz, and D. M. Weary. 2006. Brisket boards reduce free-stall use. J. Dairy Sci. 89:2003-2007.

Veissier, I., J. Capdeville, and E. Delval. 2004. Cubicle housing systems for cattle: Comfort of dairy cows depends on cubicle adjustment. J. Anim. Sci. 82:3321-3337.

Vokey, F. J., C. L. Guard, H. N. Erb, and D. M. Galton. 2001. Effects of alley and stall surfaces on indices of claw and leg health in dairy cattle housed in a free-stall barn. J. Dairy Sci. 84:2686-2699.

Wagner-Storch, A. M., R. W. Palmer, and D. W. Kammel. 2003. Factors affecting stall use for different free-stall bases. J. Dairy Sci. 86:2253-2266.

Ward, W. R., J. W. Hughes, W. B. Faull, P. J. Cripps, J. P. Sutherland, and J. E. Sutherst. 2002. Observational study of temperature, moisture, $\mathrm{pH}$ and bacteria in straw bedding, and faecal consistency, cleanliness and mastitis in cows in four dairy herds. Vet. Rec. 151:199-206.

Weary, D. M., and I. Taszkun. 2000. Hock lesions and free-stall design. J. Dairy Sci. 83:697-702.

Wechsler, B., J. Schaub, K. Friedli, and R. Hauser. 2000. Behaviour and leg injuries in dairy cows kept in cubicle systems with straw bedding or soft lying mats. Appl. Anim. Behav. Sci. 69:189-197.

Westerath, H. S., L. Gygax, C. Mayer, and B. Wechsler. 2006. Leg lesions and cleanliness of finishing bulls kept in housing systems with different lying area surfaces. Vet. J. doi:10.1016/j. tvjl.2006.05.010

Wierenga, H. K. 1990. Social dominance in dairy cattle and the influences of housing and management. Appl. Anim. Behav. Sci. $27: 201-229$ 